\title{
Chest radiography and CPOD
}

\author{
A radiografia de tórax e a $D P O C$
}

\author{
$\overline{\text { Bruno Hochhegger }^{1}, \text { Klaus L Irion }^{2}}$
}

Pulmonary emphysema and chronic bronchitis together are referred to under the acronym $\operatorname{COPD}^{(1-4)}$. It is estimated that chronic obstructive pulmonary disease (COPD) affects approximately $6 \%$ to $15.8 \%$ of the population aged above 40 years, as the data obtained by the PLATINO study for São Paulo are generalized for the whole Brazilian population ${ }^{(5)}$. Chronic obstructive pulmonary disease is the fifth leading cause of admission of patients above the age of 40 to the public health system in Brazil - 196,698 admissions into hospital per year, and expenditures of approximately 72 million Reais ${ }^{(1-5)}$.

The chronic inflmmatory process related to COPD may produce alterations affecting from bronchi (chronic bronquitis), bronchioles (obstructive bronchiolitis) to the lung parenchyma (pulmonary emphysema). Such anatomopathological alterations which are caused principally by smoking are found in varibale proportions among individuals affected by the disease, in correlation with clinical manifestations. Pulmonary emphysema (an injury that predominates in the lung parenchyma) and chronic bronchitis (injury affecting principally bronchi and bronchioles) represent the extreme manifestations of such alterations ${ }^{(1-5)}$.

The correlation between pathological anatomy and radiology in the investigation of enphysema is based on the concept that "excessive transparency at radiology results from an increased volume of air in relation to the amount of pulmonary tissues and blood which $X$-ray bemams encounter on its way ${ }^{\prime \prime(1-4,6-9)}$.

The performance of plain radiography in the investigation of COPD is quite limited since in the absence of air trapping abnormalities cannot be detected on the image $\mathrm{e}^{(1-4,10-12)}$. In such cases, the main alteration corresponds to decreased vasculature which is only noticeable very belatedly in the natural course of disease, besides representing an extremely subjective criterion.

In the presence of air trapping, the most reliable criteria include: 1 . lowered or rectified diaphragm, below and anterior to the

\footnotetext{
1. Professor of Radiology at Universidade Federal de Ciências da Saúde de Porto Alegre, MD, Thoracic Radiologist at Pereira Filho Pavilion and Center of Molecular Imaging - Pontifícia Universidade Católica do Rio Grande do Sul (PUC/RS), Porto Alegre, RS, Brazil. E-mail: brunohochhegger@gmail.com.

2. Consultant Radiologist of Liverpool Heart and Chest Hospital, Liverpool, United Kingdom.
}

sixth intercostal space at maximum inspiration; 2 . increased retrosternal clear space $(>3 \mathrm{~cm})$, with persistence at expiration; 3. elongated and verticalized heart, with largest cross-sectional diameter of $<11.5 \mathrm{~cm}$, remaining tapered even with the increase in the right ventricle; 4 . the presence of air bubbles may be inferred by the identificaiton of an avascular area of greater radiotransparency, either delimited or not by a thin white line $e^{(1-4,10-12)}$.

The great clinical issue of such radiographic findings is their nonspecifity. Within the differential diagnosis based on findings of pulmonary hyperinflation, enlargement of the right chambers of the heart with decreased intersegmental vasculature may also be identified in cases of pulmonary arterial hypertension without emphysema. Another relevant clinical scenario is represented by patients with severe asthma with all of such radiographic findings, but withouth COPD. On the other hand, besides being nonspecific, such criteria are poorly sensitive. As an example one can mention air bubbles which will only be present in about one third of advanced cases of disease $e^{(1-4,10-12)}$.

As regards radiological presentation and prognosis, Simon et al. ${ }^{(10,11)}$ have developed a study on survival where $53 \%$ of their patients with chronic bronchitis diagnosed at chest radiography were death in five years, and $70 \%$ of those with emphysema, in ten years ${ }^{(10-12)}$.

Based on such data, the role of computed tomography (CT) has gained relevance in the imaging evaluation of $\mathrm{COPD}^{(6-9,13-19)}$. Despite the high variability of COPD findings at $\mathrm{CT}$, such imaging method still presents relevant advantages as compared with functional tests and other imaging methods ${ }^{(1-4,6-9,13-18)}$.

Considering the mentioned studies, the recent Brazilian consensus on COPD establishes that posteroanterior and lateral plain radiography should be routinely requested, not for defining the disease, but rather to rule out the presence other pulmonary conditions $^{(20)}$.

In the present issue of Radiologia Brasileira the readers will find an interesting article by Marcos et al. ${ }^{(21)}$. In their study, the authors perform a quantitative analysis of chest radiographs from individuals with and without COPD, determining if the data obtained from such radiographic images could classify such individuals according to the presence or absence of disease. The con- 
clusion of such study is that the variables which allow a better differentiation between those two groups are related to the diaphragm muscle. However, in spite of the possible usefulness of such signs in the differentiation between patients with and without COPD, a wide variety of conditions from asthma to pulmonary hypertension should be included in the range of differential diagnoses of such findings. Also, the academic community should be made aware of the impossibilty of differentiation amongst the most diverse presentations of COPD at chest radiography. Additionally, it should be observed that the data reported by this study present the great advantage of quantifying the findings of pulmonary hyperinflation, which is still poorly disseminated in conventional radiography and should be utilized as a resource to minimize the variation in the images interpretation.

\section{REFERENCES}

1. Irion KL, Hochhegger B, Marchiori E, et al. Radiograma de tórax e tomografia computadorizada na avaliação do enfisema pulmonar. J Bras Pneumol. 2007;33:720-32

2. Irion $\mathrm{KL}$, Marchiori $\mathrm{E}$, Hochhegger B. Tomographic diagnosis of pulmonary emphysema. J Bras Pneumol. 2009;35:821-3

3. Hochhegger $\mathrm{B}$, Alves $\mathrm{GR}$, Irion $\mathrm{KL}$, et al. Emphysema index in a cohort of patients with no recognizable lung disease: influence of age. J Bras Pneumol. 2012:38:494-502.

4. Hochhegger B, Meireles GP, Irion $\mathrm{K}$, et al. The chest and aging: radiological findings. J Bras Pneumol. 2012;38:656-65.

5. Menezes AM, Perez-Padilla R, Jardim JR, et al. Chronic obstructive pulmonary disease in five Latin American cities (the PLATINO study): a prevalence study. Lancet. 2005;366:1875-81.

6. Hochhegger B, Marchiori E, Irion K, et al. Accuracy of measurement of pulmonary emphysema with computed tomography: relevant points. Radiol Bras. 2010:43:260-65
7. Irion $\mathrm{KL}$, Marchiori $\mathrm{E}$, Hochhegger $\mathrm{B}$, et al. CT quantification of emphysema in young subjects with no recognizable chest disease. AJR Am J Roentgenol. 2009;192:W90-6.

8. Hochhegger B, Irion KL, Marchiori $\mathrm{E}$, et al. Reconstruction algorithms influence the follow-up variability in the longitudinal CT emphysema index measurements. Korean J Radiol. 2011;12:169-75.

9. Hochhegger B, Irion KL, Alves GR, et al. Normal variance in emphysema index measurements in 64 multidetector-row computed tomography. J Appl Clin Med Phys. 2013;14:4215

10. Simon G, Medvei VC. Chronic bronchitis: radiological aspects of a five-year follow-up. Thorax. 1962;17:5-8.

11. Reid L, Simon G. III. Pathological findings and radiological changes in chronic bronchitis and emphysema. Br J Radiol. 1959;32:291-305.

12. Reid L. The pathology of emphysema. Chicago: Year Book Med Publ; 1967.

13. Hochhegger $B$, Irion $\mathrm{KL}$, Marchiori $\mathrm{E}$, et al. Reconstruction algorithms and their influence in emphysema CT measurements. Acad Radiol. 2010;17:674

14. Hochhegger B, Marchiori $\mathrm{E}$, Irion $\mathrm{KL}$, et al. Are we measuring pulmonary emphysema? Respir Med. 2010;104:1073

15. Hochhegger B, Marchiori $\mathrm{E}$, Irion $\mathrm{K}$, et al. Visual vs automated assessment of emphysema. Chest. 2011;140:1384

16. Hochhegger $\mathrm{B}$, Marchiori $\mathrm{E}$, Irion $\mathrm{KL}$, et al. lodinated contrast media and its influence in emphysema CT measurements. Clin Imaging. 2012;36:160.

17. Hochhegger B, Irion KL, Marchiori E. Reconstruction algorithms and CT emphysema measurements. Radiology. 2012;263:935-6.

18. Hochhegger $\mathrm{B}$, Irion $\mathrm{KL}$, Andrade CF, et al. Congenital lobar emphysema: the role of multislice computed tomography with virtual bronchoscopy in the differential diagnosis with bronchial foreign bodies. Eur Arch Otorhinolaryngol. 2012;269:2015-6.

19. Koenigkam-Santos M, Paula WD, Gompelmann D, et al. Endobronchial valves in severe emphysematous patients: CT evaluation of lung fissures completeness, treatment radiological response and quantitative emphysema analysis Radiol Bras. 2013;46:15-22.

20. Sociedade Brasileira de Pneumologia e Tisiologia. II Consenso Brasileiro sobre Doença Pulmonar Obstrutiva Crônica - DPOC - 2004. J Bras Pneumol 2004:30:S1-S42.

21. Marcos L, Bichinho GL, Panizzi EA, et al. Classificaçāo da doença pulmonar obstrutiva crônica pela radiografia do tórax. Radiol Bras. 2013;46:327-32. 